\title{
Исследование роли фитогормонов в обновлении клеток корневого чехлика у Arabidopsis thaliana
}

\author{
Убогоева Е.В. ${ }^{1 *}$, Землянская Е.В. ${ }^{1,2}$ \\ ${ }^{1}$ Институт цитологии и генетики СО РАН, Новосибирск, Россия \\ ${ }^{2}$ Новосибирский государственный университет, Новосибирск, Россия \\ *ubogoeva@gmail.com
}

Ключевые слова: ауксин, корневой чехлик, математическое моделирование, фитогормоны, этилен

Мотивацุия и цุель: Корневой чехлик (КЧ) - небольшой орган на самом кончике корня, который обеспечивает механическую защиту апикальной меристемы, облегчает рост корня сквозь почву, участвует в восприятии сигналов гравитации [1]. КЧ - постоянно растущий орган, который, тем не менее, имеет постоянный размер, что обеспечивается балансом между процессами деления стволовой клетки и слущивания дистального слоя дифференцированных клеток КЧ в почву. Несмотря на важность КЧ для корня и растения в целом, до сих пор остается малоизученным механизм скоординированного обновления клеток КЧ. Целью работы является исследование роли фитогормонов в этом процессе. Поскольку регуляция поддержания апикальной меристемы корня - это комплексный процесс со множеством обратных связей, для его реконструкции мы будем использовать не только молекулярно-генетические методы, но и математические модели.

Meтоды и алгоритмы: Мы использовали световую и конфокальную микроскопию для оценки количества слоев КЧ у проростков Arabidopsis thaliana дикого типа и у мутантов по сигнальным путям фитогормонов. Математические модели разработаны в среде программирования MATLAB.

Pезультаты: Ранее было показано, что градиент концентрации ауксина в колумелле может регулировать деление и слущивание КЧ [2]. На основании анализа фенотипа КЧ в ответ на экзогенную обработку этиленом и мутантов по сигнальному пути этого фитогормона мы показали роль этилена в регуляции обновления КЧ. Примечательно, что и отсутствие (мутант), и избыток (обработка) этилена приводят к одинаковому фенотипу - увеличению количества слущенных слоев КЧ. С помощью математического моделирования мы предположили, что этилен влияет на скорость роста корня и на минимальный размер стволовой клетки, при котором она может начинать делиться. Обработка ауксином и цитокинином не приводит к изменению количества слущенных слоев КЧ у проростков дикого типа, но изменяет количество слущенных слоев при нарушении сигнального пути этилена.

$B b l в o \partial b l:$ Результаты наших исследований позволяют предположить, что этилен обеспечивает стабильность процесса обновления КЧ.

Благодарности: Работа поддержана грантом РНФ № 20-14-00140.

Список литературь

1. Kumpf R.P., Nowack M.K. The root cap: a short story of life and death. J. Exp. Bot. 2015;66(19):5651-5662. DOI 10.1093/jxb/erv295.

2. Dubreuil C., Jin X., Grönlund A. et al. A local auxin gradient regulates root cap self-renewal and size homeostasis. Curr. Biol. 2018;28(16):2581-2587.e3. DOI 10.1016/j.cub.2018.05.090. 